\title{
OUVIDORIA E GESTÃO PÚBLICA: UMA RELAÇÃO NECESSÁRIA
}

\author{
J. I. A. O. SILVA ${ }^{1}$, T. F. S. DE OLIVEIRA ${ }^{2}$ \\ Universidade Federal de Campina Grande \\ ORCID ID: http://orcid.org/0000-0002-0022-3090 1 \\ irivaldo.cdsa@gmail.com ${ }^{1}$
}

Submetido 28/03/2019 - Aceito 31/07/2020

DOI: $10.15628 /$ holos.2020.8459

\section{RESUMO}

A ouvidoria vem se firmando como um importante instrumento de interface entre a gestão pública e a sociedade. A trajetória não tem sido sem percalços, no entanto, tem havido avanços, notadamente no acesso à informação e transparência pública. Portanto, o problema que norteou essa pesquisa tratou de saber se a Ouvidoria da Universidade Federal de Campina Grande (UFCG) está contribuindo efetivamente para o controle social e para a melhoria da gestão universitária? Desse modo, o objetivo geral desenhado foi fazer um diagnóstico da Ouvidoria da UFCG, para entender como este órgão vem contribuindo com a gestão estratégica e com o controle social na universidade. Os objetivos específicos foram: analisar o quadro de processos da Ouvidoria; entender como vem se dando e quais possibilidades existem no apoio da Ouvidoria à gestão da UFCG; entender as possibilidades de controle social da administração da UFCG através da Ouvidoria; verificar as possibilidades de melhorias gerenciais da Ouvidoria, tendo como hipótese que a mesma exerce uma importante função na gestão pública e no controle social, porém, esses órgãos universitários não conseguem atingir esse objetivo. A metodologia constou de uma abordagem descritiva com recursos à pesquisa bibliográfica, aplicação de questionários e análise documental. Assim, estruturamos o presente artigo numa demonstração histórica da relevância das ouvidorias, sua trajetória, com foco nas públicas, notadamente as universitárias e no caso brasileiro, escolhendo-se o modelo implementado na Universidade Federal de Campina Grande. Em seguida coloca-se uma seção com o detalhamento dos resultados das observações e verificações realizadas na análise dos processos da ouvidoria dessa instituição de ensino. Concluímos que é preciso melhorar os procedimentos, torná-los mais acessíveis, informar a comunidade acerca das funções da ouvidoria, dar autonomia à ela e aproximá-la do processo de formulação de políticas nas instituições.

Palavras-chave: ouvidoria; controle social; gestão pública.

\section{THE OMBUDSMAN`S AND PUBLIC MANAGEMENT: A NECESSARY RELATIONSHIP}

\section{ABSTRACT}

The ombudsman's office has established itself as an important interface tool between public management and society. The trajectory has not been smooth, however, there have been advances, notably in access to information and public transparency. Therefore, the problem that guided this research was to know if the Ombudsman of the Federal University of Campina Grande (UFCG) is effectively contributing to social control and to the improvement of university management? Thus, the general objective designed was to make a diagnosis of the UFCG Ombudsman, to understand how this body has been contributing to strategic management and social control at the university. The specific objectives were: to analyze the Ombudsman's process framework; understand how it has been happening and what possibilities exist in the Ombudsman's support for the UFCG management; understand the possibilities of social control of the UFCG administration through the Ombudsman; verify the possibilities for managerial improvements in the Ombudsman's Office, assuming that it has an important role in public management and social control, however, these university bodies are unable to achieve this objective. The methodology consisted of a descriptive approach with resources to bibliographic research, application of questionnaires and documentary analysis. Thus, we structured this article in a historical demonstration of the relevance of ombudsmen, their trajectory, with a focus on public, notably university students and in the Brazilian case, choosing the model implemented at the Federal University of Campina Grande. Then there is a section detailing the results of the observations and verifications carried out in the analysis of the ombudsman processes of this educational institution. We conclude that it is necessary to improve the procedures, make them more accessible, inform the community about the ombudsman's functions, empower it and bring it closer to the policy-making process in the institutions.

Keywords: ombudsman; social control; public administration. 


\section{INTRODUÇÃO}

O modelo gerencial proposto após a redemocratização brasileira, notadamente com a Reforma da Administração Pública, traz a dinâmica do mercado e as primeiras concepções de participação e controle social para a rotina estatal brasileira. Observou-se a necessidade de criar canais de comunicação do cidadão com o Estado, que possibilitassem a melhoria da gestão através do controle interno de processos e da participação da sociedade. Neste contexto gerencialista e de nascimento da democracia brasileira, origina-se a Ouvidoria Pública no Brasil, um setor multitarefas, valorizado pela Nova Administração Pública e pela gestão social, com grandes possibilidades de contribuição gerencial e de consolidação da democracia através da indução da participação da sociedade civil no controle social. Dessa forma, a pergunta que se fez nesta investigação foi se a Ouvidoria da Universidade Federal de Campina Grande (UFCG) está contribuindo efetivamente para o controle social e para a melhoria da gestão da instituição?

A Constituinte define o Ministério Público como o órgão que herdou a autonomia, as responsabilidades e o poder coercitivo do ombudsman de inspiração europeia, relegando a Ouvidoria a mero canal de atendimento de reclamações, de nítida inspiração privada. Um novo modo de pensar o campo da administração pública vislumbra olhar diferente para a efetividade do controle social através da Ouvidoria, resgatando parte das oportunidades democráticas nos primeiros anos pós-redemocratização e da Reforma.

As primeiras ouvidorias públicas foram criadas no começo da década de 90 do século passado e nasceram da necessidade de adotar mecanismos de participação social voltados à melhoria da gestão pública. Com o passar do tempo tais órgãos ganharam notoriedade e novas responsabilidades, multiplicando-se, reinventando-se e chegando ao modelo de Ouvidoria Democrática que existe atualmente. Tal modelo vem dependendo muito do perfil dos gestores que administram o órgão e da autonomia que lhe é garantida. Tais aspectos influenciam na escolha entre qual paradigma de administrar será seguido e a natureza democrática, em muitos casos, é relegada a uma mera instrumentalidade sem impacto na realidade social.

Dessa forma levou-se em consideração que a ouvidoria na Universidade Federal de Campina Grande é um setor novo, tendo entrado em exercício em 2007. As possibilidades de apoio à gestão e realização do controle social a torna significativa para os gestores, usuários internos e externos. O objetivo geral desenhado foi fazer um diagnóstico da Ouvidoria da UFCG, para entender como este órgão vem contribuindo com a gestão estratégica e com o controle social na universidade. 0 objetivo principal se desdobra em outros objetivos específicos, quais sejam: analisar o quadro de processos da Ouvidoria; entender como vem se dando e quais possibilidades existem no apoio da Ouvidoria à gestão da UFCG; entender as possibilidades de controle social da administração da UFCG através da Ouvidoria; verificar as possibilidades de melhorias gerenciais da Ouvidoria para que o apoio à gestão estratégica e ao controle social se efetivem na UFCG. 


\subsection{Metodologia}

Diante da perspectiva teórica, fizemos essa investigação visando aplicações práticas na seara administrativa. Obtivemos da análise do conteúdo e dos dados pesquisados, nas fontes eleitas para tanto, o diagnóstico da Ouvidoria da UFCG e uma proposta de intervenção que observou no que este setor pode melhorar em termos de satisfazer os usuários e contribuir com a gestão da universidade como um todo. O diagnóstico respondeu se a Ouvidoria da UFCG é eficiente, eficaz e efetiva no atendimento aos usuários, na mediação de conflitos promoção da participação social e no apoio à gestão da universidade. Nossas hipóteses foram corroboradas e tal diagnóstico serviu de esteio à proposta de intervenção, que também procurou estar em confluência com os novos paradigmas de Ouvidoria, que, em nossa concepção, não precisam ser excludentes.

Utilizou-se para este trabalho a pesquisa descritiva. Descrevemos características do controle social e as relacionamos com a Ouvidoria de uma organização pública específica, no caso a UFCG. Ao abordar as características do fenômeno estudado, procuramos analisar com certa profundidade, peculiaridades gerenciais do órgão e da instituição em que se insere. A base instrumental para este tipo de pesquisa foi a análise bibliográfica, documental e de conteúdo. Como forma de explorar o fenômeno pesquisado, utilizamos o estudo de caso, uma vez que o uso do mesmo é recomendável na fase inicial de uma investigação sobre temas complexos que exijam a construção de hipóteses ou reformulação de problemas.

Aplicamos questionários considerados como fontes primárias, enquanto que os relatórios e documentos em geral, tanto produzidos pela própria Ouvidoria da UFCG, como pelas instâncias superiores da universidade, foram fontes secundárias de dados. O questionário foi aplicado com dois tipos de stakeholders da Ouvidoria: os usuários e os gestores. Além destes, os Ouvidores, que geriram o setor desde sua entrada em exercício de fato em 2007, até o ano de 2015, que é o limite temporal da pesquisa, também serão abordados. Mesmo que a pesquisa dos dados documentais quantitativos tenham delimitação de tempo menor, entre 2014 e 2015, acreditamos que questionar apenas os ouvidores dentro desta margem de tempo seria perder a oportunidade de ter uma análise mais acurada do pensamento de todos os 5 ouvidores que passaram pela gestão do órgão.

Para esta análise documental, na parte que se refere a estatísticas processuais de manifestações para a Ouvidoria, estabelecemos a margem temporal de 2014 e 2015, quando houve relatórios mais detalhados e quando começou-se a receber manifestações através do e-OUV (setembro de 2015). Mas para o serviço de SIC, utilizaremos as estatísticas que já são produzidas desde o começo da utilização deste sistema, que foi em maio de 2012.

Diante das dificuldades de se aplicar um questionário em quantidades significativas dentro de um espaço amostral de 645 usuários no ano de 2015, este espaço foi reduzido para 70 usuários que nos enviaram manifestações por e-mail, perfazendo mais de $10 \%$ do universo escolhido. 
Analisar se o cidadão que demanda algo na Ouvidoria está acessível ficou diretamente ligado ao meio que ele elegeu para entrar em contato com o setor. A acessibilidade foi facilitada na medida em que este disponibilizou possibilidades de contactá-lo. Se a mensagem do cidadãousuário chegou por e-mail ou através do Sistema Eletrônico de Informação ao Cidadão (e-SIC), os meios de contato quase-sempre foram disponibilizados para a Ouvidoria, que administra o SIC na UFCG. Enquanto que, se chegaram através do Sistema de Ouvidorias (e-OUV), há possibilidade de haver muitas manifestações anônimas, que não informam nenhuma forma de contato, o que dificulta a aplicação do questionários. Mas para que haja representatividade na amostra, aplicaremos aos usuários do e-OUV que disponibilizaram contato, até por que há questionamentos sobre este sistema de governança eletrônica.

As mensagens eletrônicas que chegaram na conta de e-mail da Ouvidoria permitiram visualizar o e-mail do cidadão. Mas há duas formas distintas de enviar tais mensagens ao setor. A primeira delas é a utilização, por parte do cidadão-usuário, de alguma conta de e-mail válida para enviar a mensagem. A segunda forma é a utilização do link "Contatos" presente no site da Ouvidoria, em que o demandante teve espaço apropriado para descrever sua demanda e apenas informou seu e-mail em campo específico. A mensagem que chegou na "caixa de entrada" não informou se ela foi proveniente de uma conta de e-mail ou da utilização do link "Contatos" na homepage da Ouvidoria. Neste caso, houve possibilidade de o e-mail informado ser incorreto, enquanto que no primeiro caso isso não ocorre.

A disponibilidade dos respondentes dependeu muito da data de ingresso de suas demandas. Quanto mais recentes tenham sido estas, mais fácil foi para os demandantes estarem disponíveis a colaborar com a pesquisa e de forma mais eficaz, tendo em vista terem maior facilidade de lembrarem da demanda.

Nos sistemas de governo eletrônico, os quais a Ouvidoria gerencia na UFCG, há pesquisa de satisfação feita pelo próprio sistema, gerando estatísticas que serão também analisadas para obtenção do diagnóstico organizacional. Porém nosso questionário foi um pouco mais amplo, pois visou verificar diferentes posicionamentos que pudessem caracterizar perfis de Ouvidoria. Por isto, tivemos que aplicar estes questionários a estes usuários dos sistemas eletrônicos esperando que eles colaborassem, mesmo já tendo participado de questionário feito pelo próprio sistema.

Os questionários aplicados foram do tipo estruturado com perguntas fechadas e abertas tanto para os usuários dos serviços da Ouvidoria como para os Ouvidores e Gestores, porém com indagações e objetivos diferentes para cada um dos atores envolvidos. Para os usuários houve perguntas que analisaram a satisfação destes, utilizando-se a escala Likert, contendo indagação com cinco níveis de satisfação ou tamanho cinco. Nas indagações que não disseram respeito à pesquisa de satisfação, as opções de resposta foram dispostas de uma forma que não induzisse a mesma e que não ficassem próximas de acordo com a natureza semelhante dessas, e sim, alternadas.

Utilizamos uma escala de cinco níveis de satisfação, do "muito satisfeito" até o "muito insatisfeito", com um ponto neutro que é o nível "nem satisfeito, nem insatisfeito". Julgamos que a utilização deste ponto neutro é importante e não o redigimos como "neutro" ou "indiferente", 
pois acreditamos que estas expressões poderiam gerar dúvida no respondente, que poderiam marcá-las por indiferença ou despreocupação com o assunto abordado. Um pré-teste foi enviado a 10 usuários recentes da Ouvidoria, tendo 4 respondentes em uma semana. Após a análise de algumas falhas, enviamos o questionário propriamente dito a 70 usuários que nos enviaram manifestações por e-mail.

Os ouvidores e gestores da UFCG não foram entrevistados e sim questionados através de indagações objetivas e duas simples indagações abertas. Levamos em conta as limitações da entrevista e a disponibilidade dos respondentes para a escolha do questionário quantitativo com algumas alternativas qualitativas e duas questões abertas com resposta supostamente simples.

\section{SURGIMENTO DAS OUVIDORIAS PÚBLICAS}

Considera-se como o primeiro modelo dos ouvidores públicos da atualidade os chamados ombudsmans, termo que remonta o fiscal nomeado pelo parlamento na Suécia do começo do séc. XIX. Como afirma Bezerra (2014), a monarquia sueca perdeu força e a população exigia mais representatividade no poder público. Os atos da recente burocracia sueca precisavam ser controlados, o que foi incumbido ao justitieombudsman, eleito pelo Parlamento, que recebia queixas e fazia inspeções, não tendo poder de anular atos administrativos, punir servidores ou decidir judicialmente.

Durante todo o século XIX a instituição do ombudsman restringiu-se à Suécia e só veio a ser adotado por outro país após a Primeira Guerra Mundial, quando a Finlândia, recém independente, o faz em 1919 sendo acompanhada pela Dinamarca apenas em 1953. Depois desses países escandinavos, o instituto foi implantado na Nova Zelândia que acabou espalhando a ideia para a comunidade de países de influência britânica.

O ombudsman teve maior expansão após a Segunda Guerra Mundial devido ao aumento das responsabilidades da Administração Pública. A partir dos anos sessenta, o ombudsman foi sendo implantado em diversos países da Europa. Como destaca Bezerra (2014), a adoção do Provedor de Justiça de Portugal em 1975 influenciou a previsão do Defensor del Pueblo na Espanha em 1978, se espalhando pela América espanhola, chegando ao Conselho Nacional de Direitos Humanos (CNDH) mexicano. O Defensor del Pueblo acumula poderes que nenhum outro da mesma natureza possui no mundo, podendo propor ações de inconstitucionalidade. Nomeação colegiada, apurações de ofício e fungibilidade dos meios de acesso são características comuns na maioria dos modelos.

De acordo com Tácito (1988) essas previsões constitucionais nos países ibéricos serviram de inspiração para o Brasil tentar instituir seu próprio ombudsman, o que foi feito através de projetos de lei nos anos de 1981, 1983 e 1984. Diferentemente do Defensor del Pueblo na Espanha, o modelo brasileiro não previu em nenhum desses projetos dar poder aos ouvidores para propor inconstitucionalidade de leis. Outros órgão foram agraciados com essa prerrogativa. 
Patrimonialismo, burocracia, gerencialismo e administração pública social convivem até hoje disputando um mesmo espaço na administração pública brasileira. Bresser-Pereira et. al. (1995) afirma que na concepção patrimonialista o aparelho do Estado é uma extensão do poder do soberano prevalecendo corrupção e nepotismo. Pinho (1998) defende que as várias reformas da administração pública brasileira, desde os anos 30 do século $X X$, tentaram desvencilhá-la do patrimonialismo, mas não obtiveram sucesso.

Abrucio (1997) mostra a definição clássica de burocracia como uma organização com estrutura rígida e centralizada, voltada ao cumprimento de procedimentos administrativos e em que bom desempenho é aquele que observa as normas legais e éticas. Demonstra o autor que a burocracia começou a ganhar uma imagem negativa com os neoliberais a partir dos anos 80 , que a trataram mais como um grupo de interesse, tendo o setor privado como o modelo ideal de gestão.

Torres (2004) afirma que no Brasil a burocracia teve que conviver com o patrimonialismo e o gerencialismo, desvirtuando o que os teóricos burocráticos formularam. Para Bresser Pereira (1995), tanto o patrimonialismo como o burocratismo estavam condenados, necessitando-se agora de estratégias administrativas baseadas na ampla delegação de autoridade e na cobrança a posteriori de resultados.

É nesta concepção gerencialista que surge a utilização do termo cidadão-cliente. Ferreira et. al. (2012) afirmam que a condição de consumidor dos serviços públicos não está atrelada ao poder de compra, e sim à titularidade de direitos individuais e sociais, podendo-se utilizar estratégias de marketing adaptadas ao setor público, com foco no "cliente". Entretanto, sobressai a necessidade fundante de participação da população de maneira direta e indireta, o que é, atualmente, sobremaneira facilitado através das ferramentas de Tecnologia da Informação (TI) que permite o monitoramento quase que em tempo real a qualidade do serviço prestado ao público. (OLIVEIRA e OLIVEIRA, 2019).

Bresser-Pereira (1996a; 1996b) utiliza o termo cidadão-cliente corriqueiramente, tendo nítida influência da NAP. Para Secchi (2009) as novas abordagens de administração pública, que tratam cidadãos como clientes de serviços públicos, valoriza a eficiência, marketization (mecanismos de mercado), accountability (responsabilização e controle) e benchmarks (observação das melhores práticas). Ribeiro e Oliveira (2013) mostram que a ouvidoria atua como fonte de informação e marketing captando anseios dos cidadãos e aproximando-os da gestão, fortalecendoa.

Motta (2013) explica que o surgimento do New Public Management (NPM) ou Nova Administração Pública (NAP) veio da necessidade de mudanças rápidas e novas soluções, favorecendo a proposição de práticas flexíveis de gestão privada no setor público. Para este autor a NAP já teve seu fim por ter desconsiderado instrumentos práticos de gestão. Seria ilusório tentar resolver problemas políticos com técnicas gerenciais, que não contornam a política. Ao mesmo tempo, defende que a gestão do Estado seja valorizada, no que podemos denotar uma necessidade técnica, mas não vinculada aos padrões privados. 
As Ouvidorias se inserem como ferramentas do gerencialismo através do apoio à gestão através de informações (banco de dados e estatísticas), sugestões (dos cidadãos usuários ou da própria Ouvidoria), parceria com os órgãos de controle e através do controle social. Os usuários são um termômetro de como a instituição a que pertence o órgão está lidando com os problemas relacionados à sua gestão e que são levados à Ouvidoria para que esta realize a intermediação para a efetiva resolução do problema junto ao setor competente na instituição. Foi o que observou

Barros (2011) ao demonstrar que a melhora na captação da opinião dos cidadãos é diretamente proporcional ao número de reclamações e outras manifestações. Quanto mais a Ouvidoria se preocupa em melhorar seu serviço e o serviço da entidade, mais reclamações recebe, o que gera um ciclo virtuoso. Em alguns setores isso é mais visível por exemplo no Sistema Único de Saúde (SUS), como afirma Oliveira e Oliveira (2019) em que essas ferramentas são essenciais para detectar os gargalos e encaminhar processos de diversas ordens deste uma licitação irregular até servidores que não cumprem sua carga horária, o que pode resultar num procedimento administrativa que culminará em alguma punição, depois do devido processo legal.

Melo (2016) apresenta a ouvidoria como advento moderno que possibilita a abertura de "caminhos" de restauração em situações de conflitos, claro que dentro de limites legais, mas pode contribuir para um melhor ambiente de trabalho e controle social dentro de uma perspectiva totalmente pública. Siqueira Melo (2016) destaca o impacto positivo que um trabalho de ouvidoria pode surtir no planejamento estratégico de uma instituição, notadamente, em instituições de caráter tão complexo e relevante como as universidades que congregam diversas atividades que precisam ser planejadas a curto, médio e longo prazos.

Porém, um grande desafio entre as ouvidorias é, certamente, a integração das informações, passando pelo uso mais intenso das ferramentas de TI, como já mencionado, desde o âmbito interno de uma instituição até no âmbito externo com o acompanhamento da própria sociedade, uma vez que é para ela que o serviço público atua, inclusive sendo financiado pela população. (Silva, 2016).

Entende-se que a ouvidoria é uma ferramenta essencial para o aprimoramento de qualquer regime democrático, pois se por acaso esse dispensar a atuação do ouvidor, o acesso à informação e a participação da população está indo de encontro às diretrizes de uma democracia. A grande demanda de uma ouvidoria concentra-se principalmente em duas modalidades, informação e reclamação. (TCERJ, 2019).

\subsection{0 caso brasileiro}

A Ouvidoria surge expressamente na Constituição através da Emenda Constitucional (EC) no 45/04, que aborda a criação das Ouvidorias do Conselho Nacional de Justiça (CNJ) e do Conselho Nacional do Ministério Público (CNMP). Com esta previsão, os órgãos de cidadania e participação social ganham status constitucional. Mas já havia incentivo constitucional à participação social com a Emenda no 19/98, que modificou o §3ㅇ do art. 37 da CF/88 para prever: 
Art. 37. [...]

§ 3ํA lei disciplinará as formas de participação do usuário na administração pública direta e indireta, regulando especialmente:

I - as reclamações relativas à prestação dos serviços públicos em geral, asseguradas a manutenção de serviços de atendimento ao usuário e a avaliação periódica, externa e interna, da qualidade dos serviços;

II - o acesso dos usuários a registros administrativos e a informações sobre atos de governo, observado o disposto no art. 5o, X e XXXIII;

III - a disciplina da representação contra o exercício negligente ou abusivo de cargo, emprego ou função na administração pública.

(BRASIL, 1988)

Pode-se dizer que as Ouvidorias públicas acumularam essas três funções previstas no parágrafo terceiro: reclamação, acesso às informações públicas e denúncia. Acrescente-se à esta lista a possibilidade de sugestões, elogios e dúvidas. O inciso II mostra que seria natural a assunção do Serviço de Informação ao Cidadão pela Ouvidoria.

O serviço constante do terceiro inciso tem duas acepções. Tanto a representação funcional como a denúncia apresentam notícia de suposto ato ilegal de agente público, mas a primeira é encaminhada por um agente público e a segunda por um particular (BRASIL, 2015a).

A representação ou a denúncia podem ser feitas através da Ouvidoria, mas o processo que julgará o servidor que tenha cargo, emprego ou função pública, e aplicará a punição disciplinar devida, não é realizado pelo órgão de cidadania. É feito um juízo de admissibilidade prévio (BRASIL, 2014a). Tal juízo se dá com a identificação do representante e do representado, da suposta irregularidade (associada ao exercício do cargo) e dos indícios já disponíveis.

A Instrução Normativa Conjunta no 01, entre a Corregedoria Geral da União (CRG) e Ouvidoria Geral da União (OGU), de junho de 2014, trata das normas de recebimento e tratamento de denúncias anônimas. $\mathrm{O}$ seu art. 2o determina:

Art. 2‥ Apresentada denúncia anônima frente a Ouvidoria do Poder Executivo federal, esta a receberá e a tratará, devendo encaminhá-la aos órgãos responsáveis pela apuração desde que haja elementos suficientes à verificação dos fatos descritos.

§1을ecebida a denúncia anônima, os órgãos apuratórios a arquivarão e, se houver elementos suficientes, procederão, por iniciativa própria, à instauração de procedimento investigatório preliminar.

§ 2으 0 procedimento investigatório preliminar mencionado no parágrafo anterior não poderá ter caráter punitivo.

Numa interpretação antecipada e simples das normas e jurisprudências, poder-se-ia pensar haver possibilidade de juízo de admissibilidade prévio da Ouvidoria em que apuraria de maneira breve e simples se há indícios de materialidade e autoria, antes de passar o processo para o órgão apurador. Mas esta Instrução Normativa, editada pelo órgão coordenador das Ouvidorias públicas 
é muito clara no sentido de fazer da Ouvidoria mero canal informativo da representação ou denúncia.

Essa IN Conjunta não pode gerar confusão com a IN no 01 da OGU, publicada em novembro de 2014, que também abordou essa questão da apuração no seguinte sentido:

Art. 8ㅇ À denúncia recebida pela Ouvidoria, desde que contenha elementos mínimos de autoria e materialidade, será oferecida resposta conclusiva (...).

$\S 1$ N No caso da denúncia, entende-se por conclusiva a resposta que contenha informação sobre encaminhamento aos órgãos competentes de controle interno ou externo e sobre os procedimentos a serem adotados.

A Ouvidoria, portanto, para as normas que a instruem, poderá receber representação ou denúncia, mesmo que anônima, a qual encaminhará para o órgão responsável pela apuração e ao órgão de controle interno e externo, não devendo proceder em apurações investigativas.

O quadro de serviços das Ouvidorias públicas só estará completo se for inserido o controle social. Na tentativa de impulsionar a efetividade da participação social, vários anos depois de ser mencionada na Reforma proposta pelo Ministério da Administração e Reforma do Estado, foi publicado o Decreto 8.243 de 2014, que, dentre outras atribuições, instituiu a Política Nacional de Participação Social - PNPS. A participação social promovida por esta norma procurou agregar ao poder das tradicionais instâncias de representação política a construção de um sistema de participação democrática direta, tornando-a mais completa do que a que fora idealizada pelos

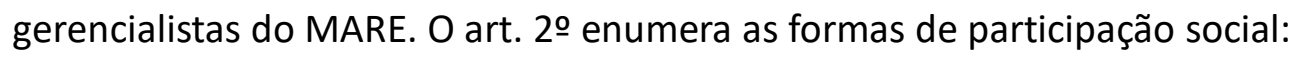

Art. 2ㅇ Para os fins deste Decreto, considera-se:

(...)

V - Ouvidoria pública federal - instância de controle e participação social responsável pelo tratamento das reclamações, solicitações, denúncias, sugestões e elogios relativos às políticas e aos serviços públicos, prestados sob qualquer forma ou regime, com vistas ao aprimoramento da gestão pública;

(...)

(BRASIL, 2014b, grifo nosso)

O inciso quinto do artigo hora estudado é elucidativo quanto ao controle social e aprimoramento da gestão da entidade que o atendimento e tratamento às manifestações de ouvidoria podem gerar. Apesar disso, alguns usuários e gestores persistem em confundir este instituto com uma mera central de atendimento, sem qualquer influência gerencial ou social relevante.

Diferentemente dos Conselhos, Comissões e Conferências, as Ouvidorias recebem demandas de cidadãos que não participam de movimentos sociais, podendo, este atendimento individual representar um problema coletivo. O grande potencial das Ouvidorias se traduz na 
oportunidade democrática, gerencial e comunicativa para a gestão pública e para os cidadãos. (BRASIL, 2012a, p. 7). Não que se exclua a participação coletiva nas ouvidorias, porém, essencialmente o caráter da ouvidoria é eminentemente receber demandas individuais que podem ter outros desdobramentos. (MACHADO e BORGES, 2017).

Entretanto, Cotta et. al. (2011) mostram que as garantias de atuação não são respeitadas e a representatividade é prejudicada por ingerências políticas. Da mesma forma, nas Ouvidorias, o contexto autoritário permanece em alguma medida, devido à falta de autonomia de alguns ouvidores. (Lyra, 2011).

Tem-se um grande arcabouço legal que apresenta a Ouvidoria como oportunidade de exercício da cidadania e também como ferramenta de gestão pública. Neste último caso o setor tem por propósito conhecer o grau de satisfação do usuário de serviço público; buscar soluções para as questões levantadas; oferecer informações gerenciais e sugestões ao dirigente do órgão, visando o aprimoramento da prestação do serviço. Portanto, no caso brasileiro, o escopo das ouvidorias é bem amplo, não devendo a mesma ficar secundarizada mas participar com protagonismo nas discussões no estágio de formulação e implementação de políticas públicas mais gerais ou setoriais.

Porém, ver-se-á que o constituinte de 1988, por motivos político-ideológicos, não escolheu as ouvidorias como protagonistas na busca da cidadania, perdendo estas a oportunidade de se tornarem órgãos independentes e verdadeiramente efetivos. A legislação, portanto, ao passo que delegou grandes responsabilidades e importância teórica e social, restringe-se a regular o parco poder que o constituinte reservou às ouvidorias públicas.

\subsection{Ouvidorias públicas universitárias}

A Constituição Federal prevê no seu art. 206, VI que a gestão democrática é princípio básico do ensino. Lenz (2014) mostra que essa previsão constitucional não afetou consideravelmente a realidade das universidades, pois a legislação não acompanhou tal previsão, e esta democratização vem dependendo da iniciativa própria dessas entidades. Tomada de decisões, composição dos colegiados e processo de escolha dos dirigentes não vem respeitando o princípio democrático previsto na Constituição. A criação de Ouvidorias Universitárias, ao contrário, vem principiando uma possível efetividade na democratização do ensino público nas Instituições de Ensino Superior Públicas.

No nível federal, estas instituições passaram por um processo de crescimento e interiorização acelerado, devido à definição das políticas de educação dos últimos 15 anos. Além do crescimento, Alves (2015) também destaca a complexidade do ambiente universitário diante da diversidade de atividades (ensino, pesquisa, extensão, atendimento comunitário e promoção cultural), que dificulta a detecção de problemas e o encaminhamento de soluções. A autora afirma que a Ouvidoria universitária pode aproximar esse espaço não só para alunos, professores e funcionários, mas também para a comunidade em geral. E essa última camada ela é fundamental para o fazer universitário, tanto como usuárias dos produtos e serviços ofertados pelas 
universidades como na própria fiscalização das suas ações.

Essa aproximação permite controle social, transparência e participação democrática no dia a dia das pessoas. Além desse fomento à participação, a autora destaca a função de intermediação entre os membros da comunidade acadêmica e os gestores, notadamente a Reitoria e PróReitorias, que ajuda na tomada de decisão sobre mitigação de infortúnios organizacionais. Pelas palavras de Alves (2015) verifica-se que a Ouvidoria é parte importante na percepção destes infortúnios. Mas não só a existência e eficácia da Ouvidoria é importante nesta percepção, mas o comprometimento da gestão da entidade na utilização do serviço deste setor, resultando em aprimoramento da gestão.

Além da participação democrática, a Ouvidoria influencia na gestão estratégica da universidade como um todo. Quando se fala neste nível de gestão está-se abordando o nível hierárquico mais alto, que realiza o planejamento estratégico. Para Araújo (1996) planejar o cumprimento de metas e objetivos tendo em vista uma missão delineada, tentando conhecer o ambiente em que se atua, não é tarefa fácil na universidade, diante da multiplicidade de atores sociais, da ambiguidade e falta de mensurabilidade das metas, bem como da falta de articulação entre os setores administrativos.

Para Alves (2018) e Falqueto et. al. (2019), as universidades precisam produzir e receber informações para dar origem a um planejamento estratégico consistente, baseado em fatos e necessidades reais no contexto local, regional, nacional e internacional; e o que temos por agora são setores que não se conhecem, tão pouco se comunicam, sendo a comunicação um grande problema que precisa da mediação da ouvidoria.

Estrada (2000) também aborda a multiplicidade de interesses como dificuldade para este planejamento e acrescenta outras: o plano de gestão não é seguido; falta integração entre ambiente externo e interno; a missão e visão da instituição não são discutidas nem divulgadas. Para Lima (2012) a relação da Ouvidoria com os gestores e não só com os usuários é primordial para a eficiência (bem executado a um baixo custo), eficácia (escolha correta de caminhos viáveis para se chegar aos resultados) e efetividade (resultados permanentes) deste setor. Levando a análise para a gestão pública universitária, a relação do setor com os setores gerenciais na universidade, portanto, torna-se essencial e, para tanto, necessária a desconstrução da imagem da Ouvidoria como órgão que apenas expõe os defeitos da gestão, gerando instabilidade institucional.

Shiroma e Campos (2006, p.12), analisando o gerencialismo na gestão educacional, falam da instituição de uma nova linguagem para promover mudança na cultura da escola, fundado no discurso do cidadão proativo. Estes autores criticam os espaços de participação, pois "por sua própria estrutura, tendem a permanecer estreitamente vinculadas à iniciativa de convocação do diretor. Neste caso a participação e decisão acontecem mais no âmbito da 'ajuda para resolver problemas', e não propriamente para gestão educacional". Nas universidades, as Ouvidorias são adaptadas à rotina de gestão educacional.

À influência no clima e na gestão educacional, soma-se o papel de mediadora de conflitos. Segundo Lyra (2004) a mediação é o mais adequado instrumento para a resolução de litígios nas 
instituições universitárias, sendo intermediada por alguém isento das disputas internas do órgão, como o ouvidor, com base em procedimentos consensualmente aceitos. Para ele, mecanismos coercitivos restauram artificialmente a convivência, enfraquecendo os laços de cooperação entre os envolvidos.

O conflito mais emblemático na universidade é entre aluno e professor. Um dos maiores desafios à ouvidoria universitária é, certamente, acompanhar o cumprimento das obrigações dos professores e os conflitos destes com os alunos. Cavedon e Fachin (2002) apontam a inexistência de controle sobre a atividade docente como uma cultura de grupo que afeta a gestão universitária.

Dourado (2011) aponta que há interrelação entre educação e política no ambiente universitário e que precisamos analisar esse fenômeno à luz do que ocorre ao nosso redor, embora sua abordagem se recente de colocar a ouvidoria como ator fundamental no processo de repensar o fazer organizacional e educacional universitário. Isso se considera porque talvez ainda exista a visão de que as instituições públicas de ensino superior não precisam levar em conta a gestão de modo amplo, que se trata de um campo exclusivo de pessoas formadas e doutoras em suas áreas específicas, porém é preciso termos alguém, ou um grupo, que pense a instituição panoramicamente com base em informações o mais precisas possíveis.

Lyra (2000) também situa a Ouvidoria universitária no contexto da chamada democracia participativa, não como órgão colegiado, mas sim unipessoal, diferenciando-se dos Conselhos de Políticas Públicas. Lyra (2014) defende a criação de Conselho Consultivo, com representantes atuantes na área afim da entidade ao qual a Ouvidoria se insere. Explica o autor que tal conselho é ausente na maioria das ouvidorias, mas é peça indispensável para uma administração democrática, principalmente em Ouvidorias corporativas, cujos titulares integram a instituição fiscalizada. Além deste colegiado citado, já se viu também que é possível a criação de Conselho Gestor com poder de deliberação, assim como Conselho ou Comissão Interna de Participação Social, com natureza definida pela entidade criadora (Brasil, 2014b).

Percebe-se as possibilidades de indução à participação social através da Ouvidoria e de Conselhos ou Comissões, consultivos ou gestores, externos ou internos. Estas exequibilidades participativas através da Ouvidoria servem tanto ao controle social, como também para induzir melhoria na gestão da universidade, conforme assevera a CGU.

\footnotetext{
"Essas estruturas surgem como um mecanismo de diálogo permanente, de participação e controle social e, portanto, de exercício democrático. Ao mediar o acesso a bens e serviços públicos, constituem-se como um importante instrumento de gestão para a Administração Pública, que tem a oportunidade de elaborar e aperfeiçoar suas perspectivas e ações, bem como subsidiar a criação de políticas públicas." (Brasil, Controladoria Geral da União, 2013a, p. 8)
}

Pode parecer desnecessária a grande dicotomia entre ações gerenciais e democráticas feitas por autores como Lyra e Paes, já que quanto mais participação social, melhor a gestão, segundo a própria CGU. Para este órgão todas as ações das Ouvidorias levam à melhoria da gestão, porém, como se viu em tópicos acima, se a autonomia da Ouvidoria não for garantida, dificilmente o setor 
não passará de um mero serviço de atendimento, bem como é preciso sua aceitação pelos membros da academia como ferramenta para o reformar-se periódico do ensino superior. Além da autonomia, também nota-se que o perfil do ouvidor e a cultura organizacional, traduzida em valorização pelos gestores estratégicos, são fatores que influenciam a efetiva utilização dos serviços da Ouvidoria na gestão da instituição (Lima, 2010).

O perfil do ouvidor influencia, mas também é influenciado pelo perfil do gestor da entidade em que está inserida o órgão. O Ouvidor, por pertencer aos quadros do poder executivo, não possui a imparcialidade de um Ombudsman legislativo, que deu origem aquele. O poder e capacidade de articulação do ouvidor decorrem do poder e da importância política interna que a autoridade superior, a quem se subordina, concede à sua atuação (Brasil, 2013c).

Como foi visto, a criação da CGU em 2003, incorporando a OGU, deu um salto de qualidade na coordenação nacional das Ouvidorias federais, influenciando também outros níveis federativos. No ano de 2014, com a Instrução Normativa no 01 da OGU, as Ouvidorias federais ganharam um manual para procedimentos e posturas.

Na área de transparência, a criação do Portal de Transparência e do Sistema de Acesso à Informação também mudou a face da administração pública brasileira. Mesmo com todas estas mudanças, ainda é possível verificar a sobrevivência da cultura do sigilo, do autoritarismo, do corporativismo e da falta de procedimentos claros na condução da gestão universitária, interferindo diretamente nas possibilidades de ação da Ouvidoria, destoando de um modelo de ouvidoria como espaço democrático (Gomes et. al., 2017).

Como foi visto com Lyra (2011), parte desta mudança de postura se dá pela conquista da autonomia das Ouvidorias. Para o autor, vem sendo diferenciada a autonomia das Ouvidorias universitárias, tendo em vista a escolha dos ouvidores normalmente por um colegiado da instituição de ensino e não apenas pelo Reitor. Para Cardoso et. al. (2013) a autonomia de uma Ouvidoria possui duas dimensões: um ato normativo que permita o livre pensar e agir de seu dirigente; e mecanismos de escolha que possam garantir um dirigente esclarecido e livre.

Alves (2015), no entanto, alerta que o patrimonialismo que ainda persiste no fato de que o grupo dominante na universidade tende a não admitir um espaço público plural. Para a autora sempre haverá resistência dos grupos de poder com a Ouvidoria, pois esta pode dar maior visibilidade aos processos e procedimentos da instituição, clareando as condutas dos gestores que temem perder os privilégios conquistados. Essa transparência além de tornar claros atos administrativos ilícitos, imorais ou ineficientes, podem, ao contrário, mostrar o quanto a gestão vem sendo responsável, proba e eficiente. De todo modo a existência e funcionamento da ouvidoria deixa um saldo positivo para a instituição e à sociedade.

Para além do perfil do ouvidor e da cultura organizacional, o perfil do público a ser atendido também influencia os rumos do setor. Tem-se com Gluer (2005) que há vários públicos internos. Na universidade, tais públicos abrangem: estudantes, professores e servidores não docentes. Alguns professores e servidores são nomeados pelo Reitor como gestores, formando outra classificação componente da comunidade universitária. Para atender estes diferentes públicos, a Ouvidoria 
precisa ser dotada de capacidade de utilizar linguagens diferentes de acordo com o público atendido, o que é recomendado pela OGU na IN no 01 de 2014. Fernandes et. al. (2016) defende que há espaço para uma ouvidoria inovadora, principalmente na criação de um clima organizacional de parcerias internas e externas, que poderia ser adotado no espaço universitário.

Essa complexidade da Ouvidoria Universitária é exacerbada diante dos desafios da gestão das informações, que se torna maior na gestão destas instituições. Leitão (1985) já alertava para a ineficiência dos sistemas formais de informação nestas instituições, o que acabava gerando sistemas informais que afetavam muito a qualidade e quantidade de informações. Já Lyra (2011 e 2016) acredita que a Ouvidoria deva ser informal em seus procedimentos, como forma de aproximar o cidadão da Administração Pública. Diante desta dialética posição sobre a informalidade do órgão de cidadania, novos mecanismos de governo eletrônico nasceram da tentativa de dar mais eficiência e eficácia aos sistemas formais. Os mecanismos e-SIC e e-OUV, são exemplos desses sistemas, que estão auxiliando a gestão da informação também nas universidades, talvez estabelecendo o que Massensini (2016) chamou de governança informacional, baseada na transparência e no direito à informação.

\section{RESULTADOS}

\subsection{Quadro de Processos}

O quadro de processos apresenta dados quantitativos provenientes dos documentos e arquivos físicos e eletrônicos da Ouvidoria da UFCG. Como os relatórios que a Ouvidoria produziu nos anos de 2014 e 2015 são bastante resumidos, o acesso aos assuntos dos e-mails, processos em sistemas eletrônicos e arquivos físicos foram de suma importância para o detalhamento deste quantitativo.

As manifestações encaminhadas para a Ouvidoria da UFCG via Sistema de Ouvidorias do Poder Executivo Federal, conhecida pela sigla e-OUV, foram feitas apenas a partir de setembro de 2015, quando esta Ouvidoria aderiu ao sistema, que desde o final de 2014 havia sido disponibilizado. Tais manifestações estão contabilizadas no quadro de processos de 2015.

Seguindo o que preceitua a Instrução Normativa no 01 da OGU, de novembro de 2014, este sistema apresenta explicações aos usuários e gestores sobre como classificar a manifestação. Observando o conteúdo dos e-mails recebidos no ano de 2014 e que compuseram o quadro do relatório anual, percebeu-se que este relatório utilizou classificação das manifestações condizente com o preceituado na IN. 01/2014 da OGU. Por isto, pode-se afirmar, que mesmo com os diferentes espaços amostrais dos dois relatórios anuais, há condições de haver comparabilidade entre as estatísticas de tipo de demanda entre os dois anos pesquisados. O fato do e-mail ser o meio de acesso mais utilizado também corrobora com esta possibilidade de análise comparativa.

O conceito de processo na Ouvidoria é bastante complexo. Uma destas complexidades diz respeito aos processos físicos, arquivados no setor, que não dizem respeito aos serviços prestados, pois tratam de assuntos como diárias, transportes, passagens, relatórios, eventos da Ouvidoria ou informes institucionais. Como o setor realiza um trabalho mensal de Ouvidoria Itinerante, muitos 
dos memorandos que geraram processos arquivados dizem respeito a diárias e transportes. Esse serviço é interessante por ressaltar a caraterística de órgão que tem uma conduta de busca ativa da demanda indo aos diversos setores além da sede, Campina Grande, e mais 6 campi universitários realizando um trabalho de orientação e composição de conflitos, além do encaminhamento das demandas para os setores competentes. Isso é respaldado na literatura que aborda um modelo proativo de ouvidoria, marcada pela autonomia (OLIVEIRA e OLIVEIRA, 2019; FERNANDES, 2016).

Outra complexidade é a resolução de demandas sem processo físico. Isto se dá nos sistemas eletrônicos e-SIC e e-OUV, no e-mail e também nas demandas presenciais de pronta resposta, ou ainda, em denúncias arquivadas sem processo, em que, numa verificação prévia, a Ouvidoria observou a falta de indícios de autoria e materialidade do ilícito. Apenas algumas delas, pela complexidade, precisam ser enviadas pela via de memorando, para o setor competente. Todo memorando já é um processo escrito. Entretanto, é preciso reforçar que esse acesso aos canais será tanto maior quanto mais fáceis e intuitivos forem os instrumentos de modo a traduzir a demanda do usuário para a ouvidoria, afinal o que vai importar ao primeiro é a resposta, e que essa resposta seja célere, se vai ser positiva ou não às suas necessidades já não é algo certo.

Nessa linha, Ribeiro et. al. (2011) aponta que ainda é preciso melhorar a qualidade da informação, devendo ela ser de fácil entendimento o que poderá facilitar ou dissuadir uma futura demanda ou reclamação em órgãos estatais ou, em havendo, o usuário ficará a par de todas as informações.

Tabela 1 - Processos físicos em 2014 e 2015

\begin{tabular}{lcc|cc}
\hline TIPOS DE DEMANDA & \multicolumn{2}{c|}{2014} & \multicolumn{2}{c}{2015} \\
& Todos os tipos & Apenas físico & Todos os tipos & Apenas físico \\
“De Ouvidoria" & 447 & 61 & 645 & 93 \\
Pedidos de Acesso & 70 & 10 & 76 & 15 \\
TOTAL & 517 & 71 & 725 & 108 \\
\hline
\end{tabular}

Fonte: próprio autor

A tabela 1 demonstra que os serviços de Ouvidoria e de informação ao cidadão (SIC), produziram em 2014 e 2015179 processos em papel (meio físico e não eletrônico). A maioria se transformou em processo físico através de memorando da Ouvidoria ao setor responsável. Outras, já foram protocoladas por escrito pelo usuário do setor, que levou o documento diretamente à Ouvidoria, ou ao setor de Protocolo.

Na Tabela 1 foram protocolados 146 pedidos de acesso nos anos de 2014 e 2015, e todos via sistema e-SIC. Do e-OUV surgiram 19 manifestações no curto período de existência deste sistema na UFCG. Além destes, todos os e-mails comunicando manifestações para resposta ou conhecimento dos destinatários são considerados processos pela Ouvidoria da UFCG, em respeito ao princípio da instrumentalidade das formas, em que se privilegia o objetivo comunicacional e o 
interesse público na celeridade processual. Tal instrumentalidade é observada acrescentando-se o princípio do informalismo em que o ato, mesmo praticado de uma outra forma, será válido se atendeu o objetivo que pretendia. Os dados demonstram que a possibilidade de realizar, ou abrir a demanda, remotamente facilita e não represa as necessidades dos indivíduos usuários da instituição em qualquer dimensão. A própria variabilidade de formas de ingresso atende certamente a diversas faixas de público.

Tabela 2 - Quantitativo do tipo de demanda apresentada em 2014 e 2015

\begin{tabular}{l|c|c|c|c}
\hline TIPOS DE DEMANDAS & \multicolumn{2}{|c}{2014} & \multicolumn{2}{c}{2015} \\
Denúncias & QTD & $\%$ & QTD & $\%$ \\
Reclamações & 20 & $3,9 \%$ & 39 & $5,4 \%$ \\
Dúvidas & 290 & $56,1 \%$ & 352 & $48,6 \%$ \\
Sugestões & 131 & $25,3 \%$ & 241 & $33,2 \%$ \\
Elogio & 5 & $1 \%$ & 10 & $1,4 \%$ \\
Pedidos de acesso & 1 & $0,2 \%$ & 3 & $0,4 \%$ \\
TOTAL & 70 & $13,5 \%$ & 76 & $10,5 \%$ \\
\hline
\end{tabular}

Fonte: próprio autor, adaptado dos Relatórios da Ouvidoria

Na tabela 2 a "reclamação" é o tipo de demanda que mais aporta na Ouvidoria. Entretanto, é importante salientar que as dúvidas provindas de contato telefônico não foram contabilizadas de nenhuma forma, apesar deste meio poder ser utilizado para dar início a processo no setor. Porém, esse dado não deve ser contabilizado como negativo propriamente, desde que a instituição saiba compreender o teor dessas reclamações verificar sua procedência e levar em consideração em possíveis mudanças ou planejamentos estratégicos que possam ser formulados.

Às vezes o problema está na capacidade das instituições em tomarem decisões com uma certa rapidez, esse é o caso muitas vezes da universidade que possui um perfil organizacional complexo composto por diversos colegiados e conselhos, o que na prática dificulta uma tomada de decisão rápida. Porém, é preciso compreender se essa organização está discutindo internamente esses números e o teor dessas reclamações ou se apenas se transforma em mais uma estatística que não é levada em consideração no pensar e repensar gerencial da academia. Além disso, é preciso pensar esses procedimentos em termos de quem toma a iniciativa de reclamar e contra o que ou contra quem.

Como se está no contexto de uma instituição de ensino e a relação entre aluno e professor é um relação de poder simbólica, ou mesmo explícita, muitas vezes isso pode ser um obstáculo na 
atuação da ouvidoria. É complexo tratar algumas questões com profissionais que são referência acadêmica em determinadas áreas, mas que não são infalíveis e que, muitas vezes, não admitem ser questionado, não considerando que o campo pedagógico não é fácil para ninguém.

Quando da criação e sistematização das Ouvidorias públicas, as dúvidas não faziam parte do conjunto de manifestações possíveis de serem feitas ao setor. A Controladoria Geral da União considera o trabalho das Ouvidorias em tais consultas como um desvirtuamento do setor. Como os mais recentes estudos sobre este setor revelam, o tratamento, o encaminhamento e a resposta às "dúvidas" foram sendo incorporados na prática cotidiana.

Enquanto o Relatório de 2014 contabilizou apenas os dados provenientes das comunicações por e-mail, o de 2015 analisou também os contatos presenciais, os processos escritos e os processos eletrônicos, o que aumentou o número de manifestações. Se subtrair os 76 pedidos de acesso à informação pública, as 10 manifestações protocoladas através do e-OUV, e as 24 demandas presenciais devidamente registradas, o resultado é de 615 demandas provindas apenas de e-mail no ano de 2015. Com esse número já é possível dizer que houve 98 manifestações a mais que 2014. A virtualização dos procedimentos, certamente, facilita o fluxo processual e o acesso, bem como pode incentivar aqueles que de outra forma não iriam se pronunciar perante a ouvidoria. $\mathrm{O}$ ambiente virtual tem sido utilizado para diversas finalidades que tem expandido o acesso à informação, educação e outros questões importantes para o cotidiano. (NOVELI \& ALBERTIN, 2017).

Apenas 24 demandas presenciais foram registradas em 2015, o que não corresponde ao número real. Isso se explica pela falta de mecanismo mais eficiente que possa registrar demandas de pequena monta como dúvidas simples, por exemplo, e que entreguem segurança jurídica a quem espera uma solução que foi combinada apenas verbalmente. Além disso, muitas demandas que poderiam ser presenciais se tornam eletrônicas. A preferência pelo registro eletrônico é uma recomendação da CGU.

Uma ferramenta importante para o saneamento de dúvidas, que ainda não é utilizado da maneira devida pela UFCG, é a Carta de Serviços ao Cidadão, contendo informações importantes e detalhadas de quais serviços são prestados, além de outras que podem ser acessadas para fins de controle social.

A Tabela 2 aponta, ainda, um baixo interesse em realizar sugestões à gestão. Entretanto, é preciso elaborar estratégias para incentivar essas contribuições que podem servir de subsídio para planejamento institucional. A baixa quantidade de elogios também é sintomático. Também se pode observar que, além das manifestações originais, há pedidos de acesso à informação pública, que, na UFCG, também é responsabilidade da Ouvidoria. Porém, isso está em acordo com relatórios acerca da atuação de outras ouvidorias, uma vez que preponderam as reclamações e denúncias. (TCERJ, 2019; UFG, 2019; ANS, 2020). Não é possível saber se ausência de sugestões é fruto de desconhecimento do funcionamento ou simplesmente desinteresse.

Ao adicionar o número de pedidos de acesso à informação pública pode-se perceber que a quantidade é considerável. Em termos qualitativos, a complexidade destes pedidos pode ser bem 
maior que a da maioria das reclamações e dúvidas. A Ouvidoria precisa traduzir os pedidos para uma linguagem perceptível aos gestores da universidade, enquanto estes, precisam cumprir o prazo e os requisitos para negar ou conceder o acesso. As respostas, a linguagem e os motivos precisam estar de acordo com o que preceituam as normas que ditam este Sistema (Lei de Acesso à Informação - 12.527/2011 e Decreto 7.724/2012).

Tabela 3 - Quantitativo do tipo de público atendido em 2014 e 2015

\begin{tabular}{l|c|c|c|c|} 
TIPOS DE PÚBLICO ATENDIDO & \multicolumn{2}{|c|}{2014} & \multicolumn{2}{c|}{2015} \\
Alunos & QTD & $\%$ & QTD & $\%$ \\
Docentes & 224 & $51,6 \%$ & 298 & $54,3 \%$ \\
Servidores técnicos & 42 & $9,7 \%$ & 48 & $8,4 \%$ \\
Sociedade civil & 22 & $5,1 \%$ & 51 & $13,30 \%$ \\
Vestibulandos & 44 & $10,1 \%$ & 111 & $23,8 \%$ \\
\hline TOTAL & 102 & $23,5 \%$ & ---- & ---- \\
\hline
\end{tabular}

Fonte: próprio autor

Segundo a tabela 3, sem contar os pedidos de acesso à informação, o quantitativo de manifestações foi de 447 (2014) e 569 (2015), o que é superior aos 434 (2014) e 508 (2015) demandantes, dos diversos seguimentos. Isto se explica pelo fato de ser possível ao demandante apresentar, numa única demanda, várias manifestações diferentes. Por exemplo, um estudante apresenta dúvida sobre procedimento de matrícula e ao mesmo tempo denuncia determinado servidor por conduta incompatível. Ou um processo de reclamação acompanhado de sugestão.

Nos dois anos, a maior quantidade de alunos ou discentes atendidos em relação aos outros segmentos é notória. Com esses números poderia até mesmo se pensar em tratar a Ouvidoria como um setor de atendimento aos alunos, porém é um setor voltado à comunidade acadêmica como um todo, e também à comunidade não vinculada diretamente à universidade. Mas a necessidade de ser um canal que considere as particularidades deste tipo de seguimento é notória. $\mathrm{O}$ ambiente universitário é muito complexo, muitas relações de poder veladas e explícitas, talvez o número de denúncias de alunos contra servidores demonstre uma quebra desses paradigmas e uma preocupação de melhorar a relação professor e aluno, bem como o ensino aprendizagem. Talvez seja importante avançar no sentido de verificar a satisfação desses atores com o ambiente universitário, uma variável nem sempre levada em consideração. (Santos et. al., 2013).

Considerou-se que os funcionários terceirizados são pertencentes à comunidade acadêmica, pois mesmo não possuindo vínculo estatutário com a autarquia, possuem vínculo de trabalho, cultural e social. O terceirizado, apesar de contratado por interposta empresa participa do convívio e do serviço prestado pela universidade. A diferença entre serviços fins e meio cai por terra diante da imprescindibilidade destes profissionais para uma composição organizacional. Não 
foi sem motivo que o Relatório de 2015 apresentou as manifestações dos terceirizados junto a dos servidores técnicos.

\subsection{Resolutividade}

A complexidade do indicador de resolutividade está em interpretar o que seria a resolução do serviço. Para a maioria dos serviços realizados pela Ouvidoria da UFCG, através do atendimento às manifestações dos usuários, a resolução do serviço se dá com a resposta conclusiva, que pode ser uma resposta que agrade ou desagrade o requerente, não tendo a resolutividade relação com o atendimento da vontade do requerente.

A resolutividade também vai depender do tipo de manifestação que é enviada à Ouvidoria, pois caso seja uma simples dúvida, basta a Ouvidoria saná-la para encerrar-se o processo. Assim também acontece com o elogio e a sugestão, que não tem obrigatoriedade de resposta, sendo resolvido com o recebimento do elogio pela chefia imediata, ou pelo membro da comunidade acadêmica, normalmente um gestor, responsável por receber a sugestão. Diferente da denúncia, reclamação e solicitação de providências em que não cabe à Ouvidoria atender o desejo do requerente, e sim, providenciar a resposta. É essa compreensão sobre a função de mediação da ouvidoria. Ela é mediadora, ou seja, ela encaminha para a resolução das demandas que exigem uma resposta. Porém, talvez, muitos dos atendidos por esse serviço não tenham essa compreensão, entendendo que a ouvidoria é uma instância de resolução. (ALVES, 2018; FERNANDES et. al., 2016; Melo, 2016).

$\mathrm{Na}$ análise dos dados provenientes do e-OUV percebeu-se uma baixa resolutividade. Para o cálculo da resolutividade geral somou-se a quantidade de processos respondidos dentro dos 20 dias legais com a quantidade de processos prorrogados e com resposta dentro do prazo de prorrogação (10 dias). Esta soma dividiu-se pelo total de processos resultando no indicador de resolutividade da Ouvidoria para os anos de 2014 e 2015 juntos. Portanto, não entra nesse cálculo as manifestações do e-OUV realizadas em 2016.

Houve poucas justificativas de atraso, e estas não foram protocoladas da maneira devida nos dois anos pesquisados, tomando por base tanto Ouvidoria como SIC o que denota a necessidade de conscientizar os gestores da universidade da necessidade do cumprimento da legislação que obriga a justificativa para que seja permitida a prorrogação. Parece que há a necessidade de obediência a protocolos por todos os envolvidos com o procedimento, do contrário afetará a credibilidade do sistema. É interessante a compreensão do que é compliance, já amplamente aplicada no mundo corporativo, que precisa, talvez, ser aprofundado por organizações públicas (MADEIRA, 2016), uma vez que nada mais é do que um pacto, um compromisso, de obediência às regras da instituição e o monitoramento desse cumprimento. Dessa forma, a ouvidoria poderia implementar esse compliance e acompanhar seu cumprimento pela instituição em suas diversas dimensões. É importante indicar que esses protocolos são utilizados principalmente para regrar as condutas éticas das corporações e no setor público notadamente na prevenção e combate à corrupção (KEMPFER e BATISTI, 2017; HIJAZ, 2016)

Com isto tem-se que 942 usuários da Ouvidoria/SIC apresentaram 1242 manifestações (517 
em 2014 e 725 em 2015), tanto da Ouvidoria em si como do SIC, nos anos de 2014 e 2015, considerando que em 2014 foi registrado apenas as manifestações advindas dos e-mails. Destas 1242 manifestações ou pedidos há 1167 resolvidos dentro do prazo de 20 dias, ou com prorrogação justificada no tempo certo.

Considerando a quantidade de processos dentro do prazo em relação ao total de manifestações e pedidos de acesso, tem-se o percentual de $94 \%$ de resolutividade no âmbito da Ouvidoria da UFCG. Das 75 demandas respondidas em prazo superior a 20 dias, 22 são do SIC e 43 são demandas de ouvidoria propriamente ditas. Considerando que foram 146 pedidos de acesso à informação, os 22 atrasados correspondem a 15\%, enquanto nos outros tipos de manifestações o atraso corresponde a $3,4 \%$.

O atraso total de $6 \%$ pode parecer pouco, mas tem plenas condições de ser menor através de melhoria na gestão processual. Tal melhoria passa pela maior diligência dos gestores da UFCG quanto aos novos prazos de resposta que advém dos mecanismos de governança eletrônica criados pelo Sistema de Informação ao Cidadão (e-SIC) e pelo Sistema Federal de Ouvidorias (e-OUV).

A comparação das duas resolutividades ilustradas acima mostra que o e-SIC precisa de uma atenção especial quanto ao cumprimento dos prazos. É preciso verificar a causa destes atrasos para poder mitigá-los. A Lei de Acesso à Informação entrou em vigor em 2012, prevendo o prazo de 20 dias para resposta aos pedidos de acesso à informação pública. Os gestores estavam acostumados com prazo de 30 dias, prorrogáveis por mais 30, da Lei 9.874. Certos pedidos, apesar de razoáveis e dentro dos requisitos da LAI, demandam grande esforço dos setores, que não estavam habituados com estas exigências de transparência pública.

Além disso, é preciso a observância dos dispositivos da Lei n. 13.460, de 26 de junho de 2017, acompanhado do Decreto n. 9.094, de 17 de julho de 2017, em que as atribuições das ouvidorias públicas federais foram amplificadas com base no incentivo à participação dos usuários e na verificação da satisfação dos mesmos com os serviços prestados. Essas ouvidorias devem acompanhar o cumprimento desses serviços e envidar esforços no sentido de propor mudanças para o aperfeiçoamento dos mesmos. Isso reforça um caráter ativo e não apenas passivo das ouvidorias. Portanto, ela precisa se fazer presente.

\subsection{Fluxograma de processos na Ouvidoria}

O fluxograma 1 de processos administrativos da Ouvidoria não tem como parâmetro de análise o conceito tradicional de processo, que é aquele arquivo impresso e assinado pela autoridade competente. O conceito que se trabalhou aqui define processo como qualquer possibilidade de iniciar uma demanda do setor, seja de maneira impressa ou eletrônica. Até mesmo o telefonema por si só pode dar início a um processo administrativo na Ouvidoria, quando a manifestação será devidamente registrada por e-mail ou através de processo físico. O sentido da ouvidoria é facilitar o acesso e não burocratizá-lo.

O e-mail e os sistemas eletrônicos de governança (e-SIC e e-OUV) também dão início a processos. Nesses sistemas há produção de numeração de protocolo para cada manifestação, estando prazos processuais e cadastros dos usuários registrados eletronicamente. As demandas 
concluídas através do e-mail da Ouvidoria não geram número de protocolo. Um e-mail só gera número de protocolo se for anexado a um memorando que será enviado à parte destinatária para resposta ou apenas recebimento, no caso de não necessitar de esclarecimentos ou respostas ao demandante.

O Fluxograma 1 não é taxativo, pois o trâmite processual, seja em que estágio estiver, pode ser interrompido por decisão do usuário demandante. A interrupção de uma denúncia pode não ser considerada pela Ouvidoria, caso se observe a existência de indícios suficientes de autoria e materialidade de cometimento de falta administrativo-disciplinar, civil ou penal (crime).

No primeiro caso (ilícito disciplinar), a Ouvidoria recomendará sindicância ou processo disciplinar e nos dois outros casos (ilícito civil ou criminal) encaminhará a demanda para o Ministério Público Federal apurá-los. Tal fato acontece pela obrigatoriedade da observância de princípios do direito administrativo, notadamente o da indisponibilidade do interesse público e probidade que são feridos caso algum servidor público (técnicos ou professores) cometam ilícitos de qualquer natureza, podendo os servidores da Ouvidoria e o Ouvidor serem responsabilizados caso se omitam na comunicação destas faltas. O princípio maior desse procedimento é o da flexibilização, que é a tônica de uma sociedade informacional como o nossa. (Lima et. al., 2010).

\section{Fluxograma 1 - Fluxograma de processos na Ouvidoria/SIC da UFCG}

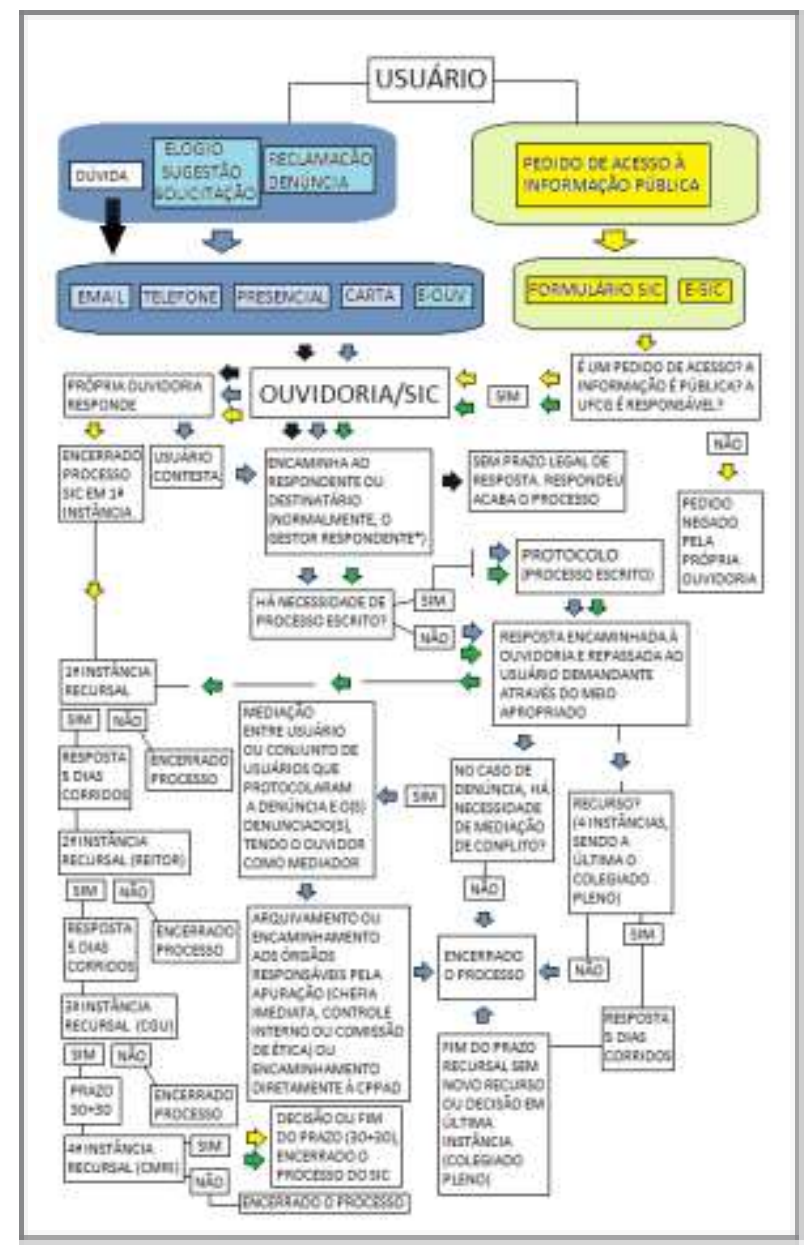

Fonte: Elaborada pelo próprio autor 
Há um destaque feito para um tipo de manifestação em especial que não é obrigação legal das Ouvidorias públicas, mas que, por vários fatores, foi incorporada por estes órgãos de modo natural. Esta manifestação é a "dúvida", que, em termos quantitativos, tem os maiores números, porém, qualitativamente, normalmente demanda um serviço de baixa complexidade.

As dúvidas, em sua maioria, são resolvidas prontamente, seja pela própria Ouvidoria que responde diretamente ao usuário, ou através do órgão da universidade relacionado com o tema objeto da dúvida. Há períodos em que este tipo de manifestação se faz mais presente, como em meses que antecedem seleções de ingresso nos cursos, concurso e, principalmente, período de matrículas ou cadastramentos dos discentes ingressantes na graduação.

É possível observar no fluxograma 5 particularidades:

- O tratamento processual das dúvidas;

- Utilização do e-OUV para todas as "demandas de Ouvidoria" que chegarem;

- Utilização do e-SIC para o caso de ser enviado pedido por e-mail ou através de formulário;

- Criação de canhoto de protocolo para os atendimentos presenciais;

- Publicação, nos vários meios de divulgação do órgão, da possibilidade de utilizar a Ouvidoria para dúvidas em geral e denúncias anônimas.

\subsection{Fluxograma da relação entre Ouvidoria e Gestão}

No tópico anterior observou-se a relação processual que existe entre a Ouvidoria e os seus usuários (podendo um gestor ser usuário da Ouvidoria), em que indiretamente o setor trata com os gestores, buscando respostas, resolução das providências requeridas ou pedindo apuração do que fora requerido. Membros da gestão da universidade podem participar dos serviços prestados pela Ouvidoria da UFCG da seguinte forma:

- Como usuário;

- Respondente da demanda apresentada por um usuário;

- Requisitante de informações gerenciais;

- Respondente de proposta de mudança gerencial feita pela Ouvidoria.

Aborda-se aqui a relação direta entre Ouvidoria e Gestão, que acontece em três casos específicos. Dois desses casos estão presentes no Fluxograma 2 e o terceiro no Fluxograma 3.

Fluxograma 2 - Relação direta Ouvidoria-Gestão 


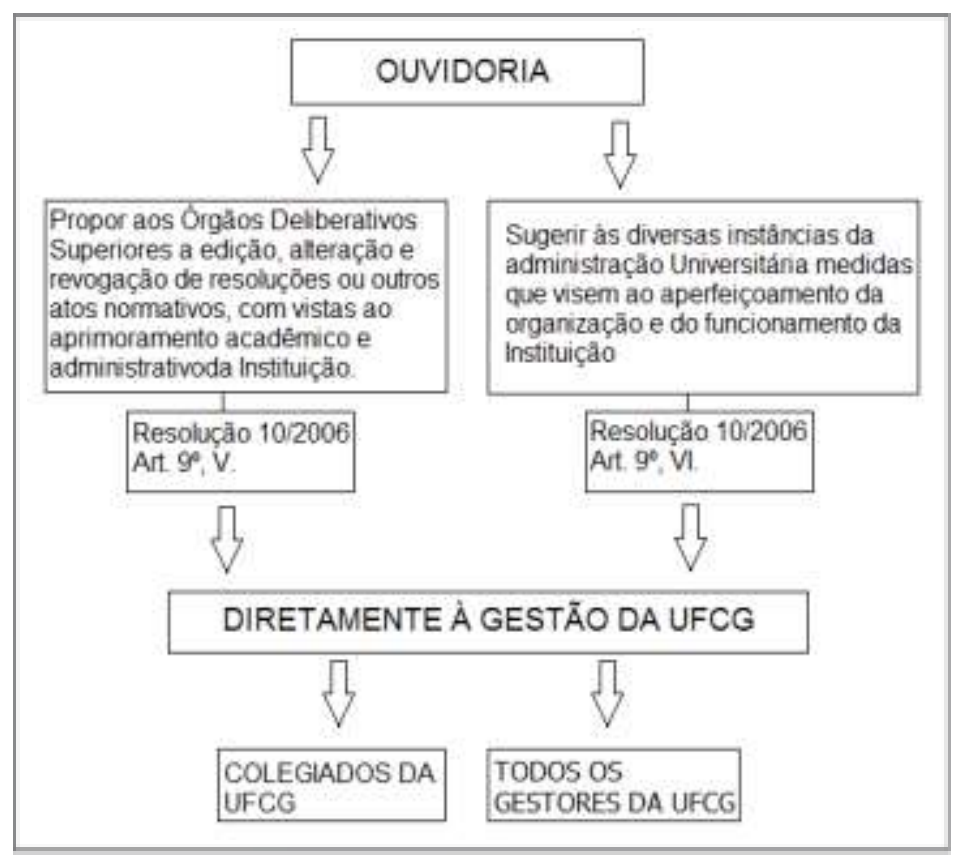

Fonte: Elaborada pelo próprio autor

A terceira relação entre Ouvidoria e Gestão, na verdade, se dá ao contrário, pois aqui a Reitoria, órgão singular máximo da instituição, e o Colegiado Pleno, órgão colegiado máximo da mesma, é que apresentam demanda à universidade. Nas relações processuais anteriores a Ouvidoria era quem demandava da gestão as respostas às manifestações apresentadas pelos usuários. Reitoria e Colegiado Pleno podem apresentar requerimento de esclarecimento ou informações à Ouvidoria. O fluxograma abaixo mostra essa relação:

Fluxograma 3 - Relação Reitoria/Colegiado Pleno - Ouvidorias

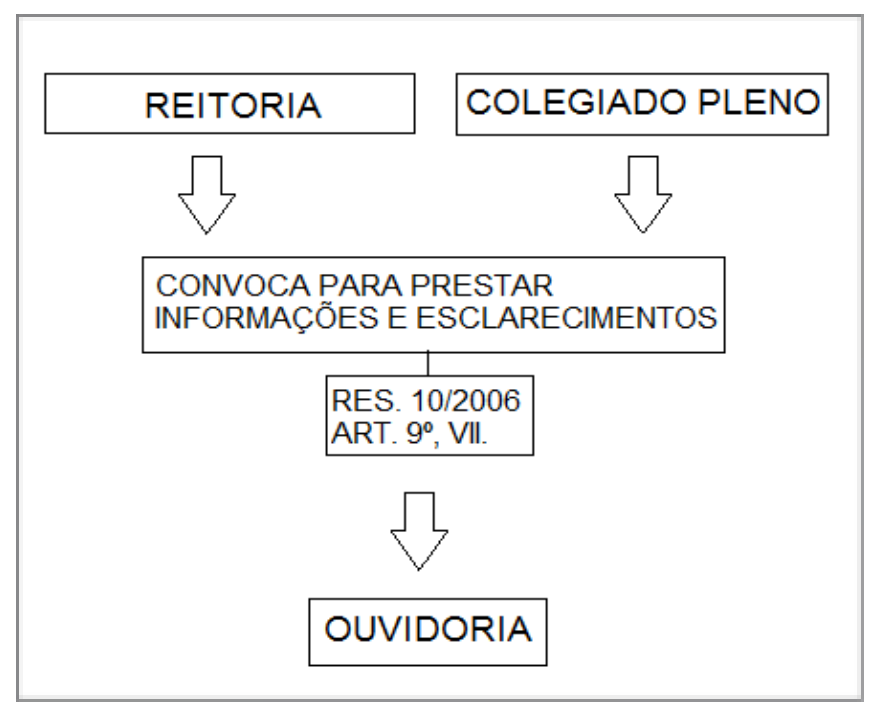

Fonte: Elaborada pelo próprio autor

Essa possibilidade de pedido de esclarecimento ou de informações dos órgãos máximos da universidade evidenciam o caráter de apoio à gestão que a Ouvidoria pode dar. O setor sozinho já produz informações importantíssimas para a gestão e que podem estar sendo subutilizadas por 
esta. A relação deste setor com o Controle Interno também colabora para a obtenção de informações importantes para o melhor gerenciamento da universidade.

\section{CONSIDERAÇÕES FINAIS}

Corroborando a hipótese inicial, o apoio à gestão e ao controle social através da Ouvidoria mostram-se ineficientes. A suposta autonomia da Ouvidoria não se reverte em resultados práticos em termos de efetividade gerencial e democrática, sendo mera intermediadora de conflitos. Porém, é preciso constatar que é fundamental o melhor acompanhamento das decisões tomadas ou mesmo das sugestões encaminhadas, além de ser necessária a implementação de diretriz que preveja uma abertura maior por parte dos colegiados e da administração central em face dos dados e constatações das ouvidorias universitárias.

A pergunta que se fez o presente ensaio foi se a Ouvidoria da UFCG está contribuindo efetivamente para o controle social e para a melhoria da gestão da universidade? A análise documental e do conteúdo dos questionários aplicados deu indícios de que a Ouvidoria não vem sendo efetiva nem no controle social e nem no apoio à gestão da universidade, o que possibilita pensar que uma das causas disso seja uma resistência ao papel da ouvidoria ou mesmo incompreensão acerca do seu papel não policial.

A análise dos dados coletados revela uma maior quantidade de conclusões negativas sobre os serviços prestados pela Ouvidoria: desconhecida, pouco transparente, pouco eficiente no combate à falta de transparência da gestão, dependente da vontade da gestão superior, pouco ou quase nada relacionada com os serviços do órgão de controle interno, omissa ou ineficiente na coleta de dados que dariam suporte ao controle interno e à gestão como um todo, ineficiente no registro das manifestações, omissa no controle social e na defesa dos direitos humanos.

A dependência da gestão superior da universidade evidencia-se pela falta de autonomia plena. Um Ouvidor eleito por um colegiado e com prazo certo de gestão poderia ser decisivo quanto à autonomia da Ouvidoria da UFCG. Porém, falta um orçamento próprio e a possibilidade mais livre de participação em reuniões de colegiados sem que necessariamente diga respeito a "assuntos pertinentes às atribuições da Ouvidoria", o que pode ensejar interpretações de gestores receosos da fiscalização ou "impertinência" da presença deste órgão.

Outra característica negativa é a ineficiência no registro das demandas presenciais, que quase não é feito pelos funcionários, restringindo-se a poucos registros da presença de determinados usuários, apontando-se o seguimento do mesmo, o contato deste e se a demanda teve restrição de identidade ou não. Não é entregue protocolo de atendimento ao cidadão. As manifestações que não são realizadas através dos sistemas eletrônicos não estão sendo registradas nestes portais, mesmo com a recomendação da CGU. Com esta ineficiência gera-se insegurança jurídica.

Por fim, nesta análise dos dados negativos, evidencia-se a omissão da Ouvidoria da UFCG quanto à busca por efetivo controle social e defesa dos direitos humanos. O referencial e os dados 
coletados sobre os processos e opiniões relacionadas ao e-SIC mostram que não há interesse pelo controle das políticas institucionais por parte da maioria dos usuários desta ferramenta, prevalecendo interesses individuais. A Ouvidoria não pode omitir-se no incentivo e na educação para o controle social, pois não há outro setor na universidade que seja mais interessado e apto a fazer tal serviço. As ouvidorias se tornaram espaços de controle social constitucionais e institucionalizados visando justamente a participação da sociedade civil na busca por direitos humanos, diferencando-se de um mero receptor de demandas individuais heterogêneas.

Apesar de ser considerado um órgão de fomento aos direitos humanos tanto pelos estudiosos da administração pública como para todos os seguimentos pesquisados, pouco ou quase nada é feito no âmbito da Ouvidoria da UFCG para a concretização deste intento. A garantia do direito de acesso à informação, por exemplo, considerado um direito humano fundamental, vem sendo buscado pela Ouvidoria, mas tem como obstáculo o sigilo, que ainda se faz presente diante da injustificada recusa omissiva ou comissiva de acesso a algumas informações públicas requeridas.

Algumas conclusões, porém, foram positivas: boa resolutividade processual, baixo custo, alto indicador de credibilidade perante o usuário e qualidade no atendimento. $O$ baixo percentual de processos atrasados, apesar da falta de pedidos de prorrogação e justificativas para os processos atrasados, demonstram um bom indicador de resolutividade processual. O baixo custo é evidenciado pela pouca estrutura necessária e já existente, sendo o gasto mais considerável feito com diárias e transporte para a realização da Ouvidoria Itinerante de periodicidade mensal, nos 6 campi fora de sede. A credibilidade é evidenciada pelo percentual de mais de $90 \%$ dos usuários que voltariam a utilizar a Ouvidoria novamente. O último dado positivo mostra a qualidade no atendimento, traduzida em presteza e linguagem acessível e cidadã utilizadas no atendimento realizado pelos integrantes da Ouvidoria.

Muitos defensores da Nova Administração Pública diriam estar diante de um setor efetivamente competente, tendo em vista o baixo custo, a imparcialidade, bom indicador de credibilidade perante os usuários e os bons resultados de resolução dos processos dentro do prazo. Tal competência gerencial poderia ser colocada em dúvida pela falta de pesquisa de satisfação, registro ineficiente das manifestações e divulgação precária dos serviços de um setor relativamente jovem e ainda bastante desconhecido por parte da comunidade. Além disso, não se coaduna com a realidade da gestão pública mais economicista que busca resultados orçamentários apenas. Se os resultados não influem na gestão como um todo e não tem como premissa consequências sociais, não se está diante de um setor competente e efetivo.

A grande quantidade de propostas de melhoria para a Ouvidoria da UFCG, tanto as imediatas como as de médio prazo, evidencia o quanto este setor ainda pode evoluir para ser efetivo no apoio à gestão estratégica e ao controle social. Para tanto, precisa ter uma interface prática o mais prática e acessível possível entre o cidadão e a gestão universitária. O setor pode democratizar e fomentar a participação de maneira efetiva se conseguir se tornar atraente ao usuário.

O aumento do controle social será naturalmente gradual e sempre deverá estar acompanhado dos outros mecanismos de controle, cujos processos e competências estejam muito 
bem definidas em lei. Não é preciso abandonar a burocracia, mas sim adaptá-la aos novos tempos, que exigem accountability social. O que a gestão de uma Ouvidoria Pública pode fazer é um convite ao controle social, apresentando resultados satisfatórios dos seus serviços, que devem ser prestados com linguagem acessível. A cultura do sigilo pode ser combatida com os procedimentos entregues pela burocracia legal (Lei de Acesso à Informação), mas também pela credibilidade do SIC (administrado pela Ouvidoria) e pela educação em prol da transparência ativa, encampada por este setor.

A Ouvidoria da UFCG, dificilmente, conseguirá chegar à efetiva participação social sem observar padrões mínimos de governança. Para tanto ela não pode ser eficiente e eficaz em si mesma, e sim, objetivar interferir socialmente no contexto em que está inserida. Se tiver em conta que mandato fixo é uma regra crucial para a autonomia do ouvidor da UFCG e que o órgão não pode mudar de paradigma ao sabor dos gestores que os assumem, bem como ao sabor do comportamento organizacional no decorrer do tempo, pode-se dizer que estará no caminho do controle social.

\section{REFERÊNCIAS}

Abrucio, F. L. (1997). O impacto do modelo gerencial na administração pública: um breve estudo sobre a experiência internacional recente. Disponível em: <http://repositorio.enap.gov.br/handle/1/556>. Acesso em 16 de março de 2016.

ANS -Agência Nacional de Saúde Suplementar. (2020). Ouvidoria: relatório de atividades 2019, Rio de Janeiro.

Alves, J. C. (2015). O instituto da ouvidoria como instrumento para a melhoria da gestão pública universitária: estudo de caso da ouvidoria geral da Universidade Federal do Espírito Santo. Disponível em: <http://repositorio.ufes.br/handle/10/1260>. Acesso em 25 de fevereiro de 2016.

Alves, J. F. S. A. (2018). A importância do planejamento estratégico nas universidades públicas brasileiras, IV COLBEDUCA e II CIEE 124 e 25 de Janeiro, Braga e Paredes de Coura, Portugal.

Araújo, M. A. D. de (1996). Planejamento estratégico: um instrumental à disposição das universidades?. Revista de administração pública, v. 30, n. 4, p. 74-86. Disponível em: <http://bibliotecadigital.fgv.br/ojs/index.php/rap/article/viewArticle/8028>. Acesso em 01 de novembro de 2015.

Barros, H. de. (2011). Acompanhamento das Ouvidorias do Governo do Estado de São Paulo. Dissertação, Mestrado Profissional em Gestão de Políticas Públicas, EAESP-FGV. Disponível em: <http://bibliotecadigital.fgv.br/dspace/handle/10438/8605>. Acesso em 15 de janeiro de 2016. 
Bezerra, H. M. S. (2014). Defensor do Povo: origens do instituto do Ombudsman e a malograda experiência brasileira. Revista Direito, Estado e Sociedade, n. 36. Disponível em: <http://www.jur.puc-rio.br/revistades/index.php/revistades/article/view/207>. Acesso em 21 de novembro de 2015.

Borges, C. F. e Machado, F. R. de S. (2017). Análise do componente ouvidoria na implementação da política de participação no SUS no estado do Rio de Janeiro. Sociologias, 19(44), 360-389. https://doi.org/10.1590/15174522-019004421.

Brasil (1988). Constituição da República Federativa do Brasil, Texto promulgado em 05 de outubro . Disponível em: <http://www.planalto.gov.br/ccivil_03/constituicao/constituicaocompilado.htm>. Acesso em 04 de fevereiro de 2015.

Brasil (2014b). Decreto 8.243, de 23 de maio de 2014. Institui a Política Nacional de Participação Social - PNPS e o Sistema Nacional de Participação Social - SNPS, e dá outras providências. Disponível em: <http://www.planalto.gov.br/ccivil_03/_Ato2011-2014/2014/Decreto/D8243.htm>. Acesso em 02 de outubro de 2015.

Brasil (2012a). Controladoria-Geral da União; Ouvidoria-Geral da União. Orientações para implantação de uma unidade de ouvidoria: rumo ao sistema participativo. Brasília: ControladoriaGeral da União; Ouvidoria-Geral da União.

Brasil (2013a). Controladoria Geral da União. Guia de orientação para a gestão de ouvidorias. Disponível em: <www.cgu.gov.br/assuntos/ouvidoria/produtos-e-servicos/consulta-

publica/arquivos/produto_5_gestao_de_ouvidorias.pdf>. Acesso em 10 de setembro de 2015.

Brasil (2013c). Controladoria-Geral da União. Ouvidoria-Geral da União. Guia de orientação para gestão de ouvidorias. Brasília - DF. Disponível em: <http://www.cgu.gov.br/assuntos/ouvidoria/produtos-e-servicos/consulta-publica/arquivos/produto_5_gestao_de_ouvidorias.pdf/view>. Acesso em 17 de junho de 2015.

Bresser Pereira, L. C. et al (1995). Plano diretor da reforma do aparelho do Estado. Câmara de reforma do Estado: Brasília. Disponível em: <http://www.bresserpereira.org.br/documents/mare/planodiretor/planodiretor.pdf.>. Acesso em 24 de novembro de 2015.

Bresser Pereira, L. C. et al (1996a). Da administração pública burocrática à gerencial. Revista do Serviço público, v. 47, n. 1, p. 07-40. Disponível em: <http://repositorio.enap.gov.br/handle/1/817>. Acesso em 24 de janeiro de 2016.

Bresser Pereira, L. C. et al. (1996b). Texto para discussão 9: administração pública gerencial: estratégia e estrutura para um novo Estado. Disponível em: <http://repositorio.enap.gov.br/handle/1/817>. Acesso em 25 de janeiro de 2016.

Cardoso, A. S. R. et al. (2013). Ouvidoria Pública e Governança Democrática. Boletim de Análise Político-Institucional. IPEA, Brasília. Disponível em:

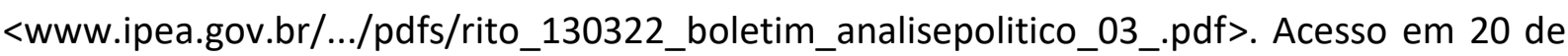
dezembro de 2015. 
Cavedon, N. R.; Fachin, R. C. (2002). Homogeneidade versus heterogeneidade cultural: um estudo em universidade pública. Organizações \& Sociedade, v. 9, n. 25, p. 61-76. Disponível em: < http://www.scielo.br/scielo.php?pid=S1984-92302002000300003\&script=sci_arttext\&tlng=pt>. Acesso em 21 de abril de 2015.

Cotta, R. M. M. et al. (2011). O controle social em cena: refletindo sobre a participação popular no contexto dos Conselhos de Saúde. Physis: Revista de Saúde Coletiva, v. 21, n. 3. Disponível em: <http://www.redalyc.org/articulo.oa?id=400838234019>. Acesso em 02 de agosto de 2015.

Dourado, L. F. (2011). Políticas e gestão da educação superior no Brasil: múltiplas regulações e controle, RBPAE - v.27, n.1, p. 53-65, jan./abr.

Estrada, R. J. S. et al. (2000). Os rumos do planejamento estratégico na universidade pública:: um estudo de caso na Universidade Federal de Santa Maria. Disponível em: <https://repositorio.ufsc.br/handle/123456789/78511>. Acesso em 06 de março de 2016.

Falqueto, J. M. Z., Hoffmann, V. E., Cancellier, É. Luís P. de Lorenzi, \& Miranda Júnior, N. da S. (2019). Avaliação da implantação do planejamento estratégico em uma universidade pública: barreiras, facilitadores e eficácia. Avaliação: Revista da Avaliação da Educação Superior (Campinas), 24(2), 357-378. Epub September 26, 2019.https://doi.org/10.1590/s141440772019000200002.

Fernandes, F. M. B., Moreira, M. R., \& Ribeiro, J. M. (2016). Análise da atuação das ouvidorias estaduais do Sistema Único de Saúde como instâncias participativas. Saúde em Debate, 40(spe), 201-212. https://doi.org/10.1590/0103-11042016s17.

Ferreira, P. A. et al. (2012). Marketing público e orientação para o cidadão-consumidor: um levantamento da produção científica brasileira entre 1997 e 2008. Gestão Pública: Práticas e Desafios, v. 3, n. 1. Disponível em: <http://seer.enap.gov.br/index.php/RSP/article/view/394/400>. Acesso em 15 de janeiro de 2016.

Gluer, L. M. (2005). A ouvidoria Universitária como espaço de interlocução com os diferentes públicos do ensino superior. In: XXVIII Congresso Brasileiro de Ciências da Comunicação. Rio de Janeiro. Disponível em: <http://www.portcom.intercom.org.br/pdfs/147536492986252418079198049097262304467.pdf. >. Acesso em 18de outubro de 2015.

Gomes A. C. S., Carvalho F. R., Bernardo G. N., Oliveira, L. D. da C., Lima, T. S., Mendes, M. M. (2017). O papel das ouvidorias e dos conselhos de saúde no sus: uma revisão integrativa de literatura, Rev. Gestão \& Saúde (Brasília) Vol. 08, n. 01, Jan. p 140-161.

Hijaz, T. F. (2016). A importância do compliance para a efetivação de medidas anticorrupção no contexto da sociedade de risco e do Direito Penal Econômico, Boletim Científico ESMPU, Brasília, a. 15 - n. 48, p. 155-190 - jul./dez.

Kempfer, M., Batisti, B. M. (2017). Estudos sobre o compliance para a prevenção da corrupção nos negócios públicos: Ética, Ciência da Administração e Direito, Revista do Direito Público, Londrina, v.12, n.2, p.275-309, ago., DOI: 10.5433/1980-511X.2017v12n2p275. 
Leitão, S. P. (1985). A questão organizacional na universidade: as contribuições de Etzioni e Rice. Revista de Administração Pública, v. 19, n. 4, p. 3-26. Disponível em: <http://bibliotecadigital.fgv.br/ojs/index.php/rap/article/view/10050>. Acesso em 25 de fevereiro de 2015.

Lenz, M. M. (2014). Gestão da Universidade pública no Brasil: análise do princípio constitucional da gestão democrática do ensino público como possível marco histórico na legislação. Disponível em: < http://www.lume.ufrgs.br/handle/10183/112062>. Acesso em 19 de setembro de 2015.

Lima, C. S. (2012). Gestão de relacionamento com líderes: desafio para o ouvidor. Revista Organicom, v. 7, n. 12. Disponível em: < http://www.revistaorganicom.org.br/sistema/index.php/organicom/article/view/261>. Acesso em 02 de novembro de 2015.

Lima, C. S. (2010). Ouvidor geral: a necessidade da ouvidoria moderna. Revista Gestão Pública: Práticas e Desafios, Recife, v. I, n. 1, fev.

Lima, I. F. de, Correia, A. E. G. C., Silva, A. K. A. da. (2010). O conhecimento e as tecnologias na sociedade da informação, Rev. Interam. Bibliot. Medellín (Colombia) Vol. 33, No. 1 enero-junio. ISSN 0120-0976.

Lyra, R. P. (2011). A ouvidoria pública e a questão da autonomia. Prima Facie, João Pessoa, v. 8, 15, Jul-Dez. Disponível em: <http://periodicos.ufpb.br/ojs/index.php/primafacie/article/viewFile/4517/5339>. Acesso em 23 de janeiro de 2015.

Lyra, R. P. (2004). Ouvidor: o defensor dos direitos na administração pública brasileira. Rubens Pinto Lyra, organizador. Autônomas x obedientes: a ouvidoria pública em debate. João Pessoa (PB): Ed. universitária da UFPB. Disponível em: <http://carceraria.org.br/wp-content/uploads/2012/07/Ouvidorias.pdf.>. Acesso em 10 de maio de 2016.

Lyra, R. P. (2000). O Ouvidor Universitário. A Ouvidoria na esfera pública brasileira (org.). Curitiba: Ed. UFPR. 315 p. Disponível em: <http://periodicos.ufpb.br/ojs2/index.php/politicaetrabaIho/article/view/6457/4033>. Acesso em 11 de março de 2015.

Lyra, R. P. (2014). Ouvidorias públicas e privadas: análise comparativa, p. 137-167. In: Lyra, Rubens Pinto (org.) A ouvidoria pública no Brasil: modelos em disputa. João Pessoa: Ed. UFPB, 349 p.

Lyra, R. P. (2016). Paradigmas de Ouvidoria pública e proposta de mudança. In: MENEZES, Ronald do Amaral (Org); CARDOSO, Antonio Semeraro Rito (Org). Ouvidoria pública brasileira: reflexões, avanços e desafios. Disponível em: <http://repositorio.ipea.gov.br/handle/11058/6601>. Acesso em 03 de junho de 2016.

Madeira, L. M. (2016). Compliance: a (rara) aplicação de instrumentos internacionais de proteção a direitos humanos pelos tribunais intermediários no Brasil. Revista Brasileira de Ciência Política, (21), 45-76. https://doi.org/10.1590/0103-335220162102.

Massensini, R. L. (2016). Governança Informacional: possibilidades de ações governamentais sistêmicas por Território de Desenvolvimento no estado de Minas Gerais, R. Ágora: Pol. públ. Comun. Gov. Inf., Belo Horizonte, v. 1, n. 1, p. 104-120, jan./jun. 
Melo, L. L. de S. (2016). A ouvidoria e sua contribuições ao planejamento estratégico, en Biagini, L. (Org.). O Papel da Ouvidoria no Contexto Acadêmico Universitário, Recife, editora UFPE.

Melo, I. V. de. (2016). Ouvidoria: o Desafio de Educar para a Cidadania, en Biagini, L. (Org.). O Papel da Ouvidoria no Contexto Acadêmico Universitário, Recife, editora UFPE.

Motta, P. R. de M. (2013). O estado da arte da gestão pública. Revista de Administração de Empresas, v. 53, n. 1, p. 82-90. Disponível em: <http://www.scielo.br/scielo.php?pid=S0034$75902013000100008 \&$ script=sci_arttext>. Acesso em 20 de junho de 2015.

Noveli, M., \& Albertin, A. L. (2017). Um estudo da virtualização de processos: o uso de mundos virtuais com foco em ensino-aprendizagem. Revista Brasileira de Educação, 22(71), e227151. Epub October 09, 2017.https://doi.org/10.1590/s1413-24782017227151.

Oliveira, D. T de.; Oliveira, A. G. de (2019). As Ouvidorias do SUS: como a Participação Popular se materializa como Ferramenta de Gestão e Política Pública? R. Tecnol. Soc., Curitiba, v. 15, n. 35, p. 290-310, jan./abr.

Pinho, J. A. G. de (1998). Reforma do aparelho do Estado: limites do gerencialismo frente ao patrimonialismo. Organizações \& Sociedade, v. 5, n. 12, p. 59-79. Disponível em: <http://www.scielo.br/scielo.php?script=sci_arttext\&pid=S1984-92301998000200003>. Acesso em 25 de juIho de 2015.

Ribeiro, M. de P.; Oliveira, E. R. (2013). Comunicação e marketing no setor público: uma prática que permite o fortalecimento da cidadania e a modernização da gestão pública. Gestão Pública: Práticas e Desafios, v. 4, n. 1. Disponível em: <http://repositorios.ufpe.br/revistas/index.php/gestaopublica/article/view/901>. Acesso em 03 de maio de 2016.

Ribeiro, C. P. de P., Pereira, A. D. S., Silva, E. A. da, \& Faroni, W.. (2011). Difusão da informação na administração pública. Transinformação, 23(2), 159-171. https://doi.org/10.1590/S010337862011000200006.

Santos, A. A. A. dos, Polydoro, S. A. J., Scortegagna, S. A., \& Linden, M. S. S. (2013). Integração ao ensino superior e satisfação acadêmica em universitários. Psicologia: Ciência e Profissão, 33(4), 780-793. https://doi.org/10.1590/S1414-98932013000400002

Secchi, L. (2009). Modelos organizacionais e reformas da administração pública. Revista de Administração Pública, Rio de Janeiro, v. 43, n. 2, p. 347-369. Disponível em: <http://bibliotecadigital.fgv.br/ojs/index.php/rap/article/view/6691>. Acesso em 27 de julho de 2015.

Shiroma, E. O. ; Campos, R. F. (2006). La resignificación de la democracia escolar mediante el discurso gerencial: liderazgo, gestión democrática y gestión participativa. In: Myriam Feldfe- ber; Dalila Andrade Oliveira. (Org.). Políticas educativas y trabajo docente: Nuevas regulaciones, Nuevos sujetos?. 1a ed. Buenos Aires: Ediciones Novedades Educativas, v. , p. 221-237. Disponível em:<http://louderdesign.net/gepeto/capitulos/viewdownload/22-capitulos/44-la-resignificacion-de-la-democracia-escolar-mediante-el-discurso-gerencial-liderazgo-gestion-democratica-y-gestion-participativa.html>. Acesso em 24 de janeiro de 2015. 
Tácito, C. (1988). Ombudsman - O Defensor do povo. Revista de Direito Administrativo, v. 171, p. 15-26. Disponível em: <http://bibliotecadigital.fgv.br/ojs/index.php/rda/article/view/45696>. Acesso em 08 de fevereiro de 2016.

Tcerj - Tribunal de Contas do Estado do Rio de Janeiro. (2019). Relatório anula - ouvidoria, Rio de Janeiro.

Torres, M. D. de F. (2004). Estado, democracia e administração pública no Brasil. Rio de Janeiro: FGV.

UFG - Universidade Federal de Goiás. (2019). Relatório primeiro semestre 2019, disponível em: https://files.cercomp.ufg.br/weby/up/221/o/Relatório_2019_1_\%281\%29.pdf, acesso em 20 de março de 2020.

\section{COMO CITAR ESTE ARTIGO:}

Silva, J. I. A. O., Oliveira, T. F. S. de. Ouvidoria e Gestão Pública: Uma Relação Necessária. Holos. 36(5), 1-32.

\section{SOBRE OS AUTORES}

\section{J. I. A. O. SILVA}

Pós-Doutor em Desenvolvimento Regional. Doutor em Ciências Sociais. Doutorando em Direito e Desenvolvimento. Pesquisador Produtividade do CNPq, nível 2. Em estágio Pós-doutoral no Programa de Pós-graduação em Direito, no Grupo de Pesquisa em Direito Ambiental e Sociedade de Risco, na Universidade Federal de Santa Catarina. Mestre em Sociologia. Especialista em Gestão das Organizações Públicas. Especialista em Direito Empresarial. Graduado em Ciências Jurídicas. Exerceu o cargo de Analista Judiciário no Tribunal de Justiça da Paraíba durante oito anos. Professor efetivo do Curso de Gestão Pública, na Unidade Acadêmica de Gestão Pública da Universidade Federal de Campina Grande. É pesquisador com ênfase em conflitos ambientais, meio ambiente, sociedade de risco, legislação ambiental, desenvolvimento sustentável, políticas públicas relacionadas ao acesso à água e saneamento. É membro atuante em diversos grupos de pesquisa. É membro da rede de pesquisa WATERLAT, http://www.waterlat.org/Members.html\#brazil. Pesquisador da Rede JUST-Side (Programa Iberoamericano de Ciencia y Tecnología). Membro da Associação Latino Americana de Sociologia - ALAS. E-mail: irivaldo.cdsa@gmail.com ou prof.irivaldo@ufcg.edu.br.E-mail: irivaldo.cdsa@gmail.com

ORCID ID: http://orcid.org/0000-0002-0022-3090

\section{T. F. S. DE OLIVEIRA}

Graduação em Direito pela Universidade Estadual da Paraíba (2008). Especialista em Direito Administrativo pela Faculdade Internacional Signorelli (2012). Mestre Profissional em Administração Pública pela UFCG (2016). É Assistente em Administração na Universidade Federal de Campina Grande desde 2010. E-mail: thifrasis@yahoo.com.br.

ORCID ID: https://orcid.org/0000-0002-8243-3568

Editor(a) Responsável: Francinaide de Lima Silva Nascimento

Pareceristas Ad Hoc: Allan Gustavo Freire Da Silva e Jassio Medeiros 


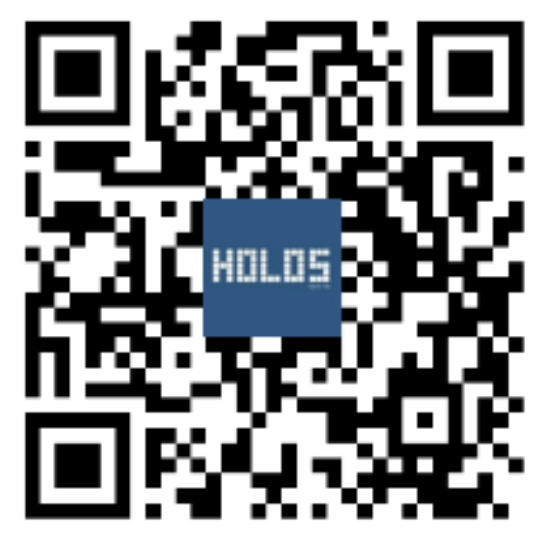

